\title{
3-Deoxyglucosone induces insulin resistance by impairing insulin signaling in HepG2 cells
}

\author{
GUOQIANG LIANG ${ }^{*}$, FEI WANG ${ }^{*}$, XIUDAO SONG, LURONG ZHANG, ZHEN QIAN and GUORONG JIANG \\ Basic Research Laboratory, Suzhou Academy of Wumen Chinese Medicine, \\ Suzhou Hospital of Traditional Chinese Medicine, Suzhou, Jiangsu 215003, P.R. China
}

Received April 25, 2015; Accepted March 1, 2016

DOI: $10.3892 / \mathrm{mmr} .2016 .5081$

\begin{abstract}
Deoxyglucosone (3DG), a highly reactive dicarbonyl intermediate generated during glycation, has been confirmed to be markedly elevated in the plasma of patients with diabetes. Our previous study found that there is an association between increasing accumulation of plasma 3DG and impaired glucose regulation in non-diabetic seniors (females, >50 years old; males, >55 years old). It was also found that $3 \mathrm{DG}$ led to impaired plasma glucose homeostasis in healthy mice, however, the mechanisms underlying the deleterious effect of $3 \mathrm{DG}$ in diabetes remain to be fully elucidated. The present study aimed to investigate the ability of 3DG to cause hepatic insulin resistance in a cell model by assessing glucose uptake and glycogen content. In addition, the molecular signaling events, including the phosphoinositide 3-kinase (PI3K)/AKT/glucose transporter 2 (GLUT2) and PI3K/AKT/glycogen synthase kinase-3 (GSK-3) pathways, which affect hepatic insulin resistance, were further investigated using Western blot analysis. The results showed that 3DG (10-300 ng/ml) had no significant effect on HepG2 cell viability, however, the viability of the HepG2 cells decreased with exposure to concentrations of 500 and $1,000 \mathrm{ng} / \mathrm{ml}$. Treatment with non-cytotoxic 3DG concentrations resulted in decreased uptake of glucose and glycogen content with insulin stimulation, but not under basal conditions. The insulin-induced expression of GLUT2 and p-GSK-3 were eliminated by 3DG (80 and $300 \mathrm{ng} / \mathrm{ml}$ ), in addition to inhibiting the phosphorylation of downstream effectors of the insulin signaling pathway, including insulin receptor substrate $1, \mathrm{PI} 3 \mathrm{~K}$ and AKT. In conclusion, the findings of the present study indicated that the
\end{abstract}

Correspondence to: Professor Guorong Jiang, Basic Research Laboratory, Suzhou Academy of Wumen Chinese Medicine, Suzhou Hospital of Traditional Chinese Medicine, 18 Yangsu Road, Suzhou, Jiangsu 215003, P.R. China

E-mail: guorongjiang@hotmail.com

${ }^{*}$ Contributed equally

Key words: diabetes mellitus, 3-deoxyglucosone, hepatic insulin resistance, impaired insulin signaling addition of exogenous 3DG directly contributed to the induction of insulin resistance by impairing insulin signaling in the HepG2 cells, which suggested that 3DG may be involved in worsening of the diabetic condition.

\section{Introduction}

Insulin resistance, defined as a process in which the peripheral tissues, including the liver, muscle and fat, become resistant to the actions of insulin, is the primary cause of type 2 diabetes (1-3). The liver has a central role in the maintenance of plasma glucose homeostasis, and the induction of hepatic insulin resistance has been reported to be important in its involvement in the development of type 2 diabetes (4). In hepatocytes, decreased glucose uptake and glycogen levels are the hallmark of insulin resistance (5-7). In addition, insulin resistance occurs at the molecular level through dysregulation in the complex network of insulin signaling pathways $(5,8)$.

3-Deoxyglucosone (3DG), a highly reactive dicarbonyl product, has been identified as an intermediate product of the Maillard reaction (9). 3DG has been reported to be associated with diabetes and other age-related human diseases (10-12). 3DG is elevated $\sim 2$-fold in plasma of patients with diabetes, and is involved in the development of diabetic complications (13-15). In addition to exerting its potent ability to form advanced glycation end-products, 3DG itself has certain biological activities, including suppression of enzyme activity during glucose metabolism and cell proliferation, induction of apoptosis and inactivation of glutathione reductase (16-18). Although evidence has indicated that methylglyoxal (MGO) induces insulin resistance, and impairs insulin signaling in Sprague-Dawley rats (19-21) and peripheral cells $(22,23)$, the concentration of MGO in a variety of foods, and the levels produced from the Maillard reaction, are lower than 3DG. In addition, Kiho et al (17) reported that 3DG inhibits the activities of hexokinase and glucose-6-phosphate dehydrogenase in crude extracts from the mouse liver.

In our previous study, it was found that 3DG led to impaired plasma glucose homeostasis in healthy mice (24) and, in non-diabetic seniors, abnormal elevations in plasma 3DG were observed, which was associated with impaired glucose regulation (25). Based on this evidence, it is reasonable to hypothesize that 3DG may be important in the development of insulin resistance. However, whether exposure to 3DG 
induces insulin resistance and impairs insulin signaling pathways directly in vitro remains be elucidated. To determine the ability of 3DG to induce insulin resistance directly, the present study determined the effect of exogenously added 3DG on glucose uptake and the contents of glycogen in the hepatocellular carcinoma, HepG2, cell line. The expression levels of insulin signaling molecules involved in insulin resistance in the hepatocytes were also investigated. The results may determine whether the addition of exogenous 3DG can directly contribute to inducing insulin resistance by impairing insulin signaling in HepG2 cells.

\section{Materials and methods}

Synthesis of 3DG. According to the method of Kato et al (26), 3-DG was synthesized from glucose. A hot solution of $6 \mathrm{~g}$ D-glucose, $3.3 \mathrm{~g}$ p-toluidine, $6.6 \mathrm{ml}$ acetic acid and $135 \mathrm{ml}$ ethanol was stirred vigorously and heated in an oil bath at $90^{\circ} \mathrm{C}$ for $30 \mathrm{~min}$. Then, $9.9 \mathrm{~g}$ benzoylhydrazine was added, followed by refluxing for 6-7 h. The reaction solution was incubated at $4^{\circ} \mathrm{C}$ overnight, then the resulting precipitate (3DG-bisbenzoylhydrazone) was collected by filtration through a Buchner funnel (Aladdin Industrial Corporation, Shanghai, China), and washed successively with $75 \mathrm{ml}$ methanol and $75 \mathrm{ml}$ diethyl ether 3 times. The product was then dried at room temperature. A solution of the 3DG-bisbenzoylhydrazone product $(3 \mathrm{~g}), 90 \mathrm{ml}$ ethanol, $1.5 \mathrm{ml}$ acetic acid, $50 \mathrm{ml}$ water and $1.6 \mathrm{ml}$ freshly distilled benzaldehyde (at $40-50 \mathrm{mmHg}, 120-130^{\circ} \mathrm{C}$ ) was refluxed at $90^{\circ} \mathrm{C}$ for $4 \mathrm{~h}$. The reaction mixture was incubated overnight at room temperature and then the filtrate was collected through a Buchner funnel and then concentrated to $70 \mathrm{ml}$ using an RE-52 rotary evaporator (Shanghai Yarong Biochemical Instrument Factory, Shanghai, China) and washed 6 times with $30 \mathrm{ml}$ diethyl ether, then decolorized with $2 \mathrm{~g}$ activated carbon. The concentrate was evaporated down to $3 \mathrm{ml}$ and $10 \mathrm{ml}$ of $95 \%$ ethanol was added. The solution was then charged on Amberlite IR120B ( $\mathrm{H}^{+}$form) and Amberlite IR4B $\left(\mathrm{OH}^{-}\right.$form) ion-exchange resin columns. The final solution was evaporated to a thick syrup, then the 3DG was purified further using a flash column (silicagel 60; chloroform/methanol/water ratio, 8.0:2.0:0.1). All chemical reagents used were purchased from J\&K Chemical, Ltd. (Shanghai, China) without further purification. The product was identified using infrared, ${ }^{1} \mathrm{H}$-nuclear magnetic resonance (NMR), ${ }^{13} \mathrm{C}$-NMR and mass spectroscopy (27).

HepG2 cell culture and treatment. The HepG2 hepatocellular carcinoma cells were provided by the School of Biology and Basic Medical Sciences, Soochow University (Suzhou, China), and were cultured in Dulbecco's modified Eagle's medium (DMEM; Gibco; Thermo Fisher Scientific, Inc., Waltham, MA, USA) containing 10\% (v/v) fetal bovine serum (Zhejiang Tianhang Biological Technology Co., Ltd., Huzhou, China) and antibiotic solution $(100 \mathrm{U} / \mathrm{ml}$ penicillin and $100 \mu \mathrm{g} / \mathrm{ml}$ streptomycin; Beyotime Institute of Biotechnology, Shanghai, China) at $37^{\circ} \mathrm{C}$ in a humidified atmosphere containing $5 \% \mathrm{CO}_{2}$. The cells were grown to $70-80 \%$ confluence and were seeded into 96/48-well plates at a density of $5 \times 10^{4}$ cells/well. The cells were then either pre-treated with $3 \mathrm{DG}(10,80$ or $300 \mathrm{ng} / \mathrm{ml})$ in serum-free medium for $24 \mathrm{~h}$, or remained untreated, with or without subsequent exposure to insulin $(2.0$ or $6.6 \mathrm{IU} / \mathrm{ml})$, for the experimental groups.

Cell viability assay. Cell viability was measured using a standard 3-(4,5-dimethylthiazol-2-yl)-2,5-diphenyltetra-zolium bromide (MTT) assay (Wuxi Zhanwang Chemical Co., Ltd., Wuxi, China). Briefly, $5 \times 10^{4}$ cells/well were seeded in 96-well microtiter plates for $24 \mathrm{~h}$ at $37^{\circ} \mathrm{C}$; the cells were then pre-incubated with or without $3 \mathrm{DG}$ at final concentrations of 10,50,80, $300,500,800$ and $1,000 \mathrm{ng} / \mathrm{ml}$ in serum-free medium supplemented with high (H-DMEM; $25 \mathrm{mmol} / \mathrm{l}$ ) or low (L-DMEM; $5.6 \mathrm{mmol} / \mathrm{l})$ glucose (Gibco; Thermo Fisher Scientific, Inc.) for $24 \mathrm{~h}$ at $37^{\circ} \mathrm{C}$. The medium was subsequently removed, and $200 \mu \mathrm{l}$ of MTT was added to a final concentration of $0.5 \mathrm{mg} / \mathrm{ml}$. After $4 \mathrm{~h}, 150 \mu \mathrm{l}$ dimethyl sulfoxide solution (Wuxi Zhanwang Chemical Reagent Co., Ltd., Wuxi, China) was added to solubilise the MTT formazan. The plates were placed on a mechanical shaker (Shanghai Centrifuge Institute Co., Ltd., Shanghai, China) for $10 \mathrm{~min}$ at room temperature, and the optical density (OD) was read at $490 \mathrm{~nm}$ using an enzyme-linked immunometric meter SpectraMax M2 (Molecular Devices, LLC, Sunnyvale, CA, USA), as previously described (28).

Measurement of glucose uptake. The glucose uptake was measured using 2-[N-(7-nitrobenz-2-oxa-1,3-diazol-4-yl) amino]-2-deoxyglucose (2-NBDG; Cayman Chemical Co., Ann Arbor, MI, USA), comparable to the study by Engelbrecht et al (29). Following treatment of the cells $\left(5 \times 10^{7}\right.$ cells/well) with or without different concentrations of 3DG in L-DMEM for $24 \mathrm{~h}$, the cells were washed with Krebs-ringer bicarbonate (KRb) buffer (4A Biotech Co. Ltd., Beijing, China) comprising $129 \mathrm{mM} \mathrm{NaCl}, 4.7 \mathrm{mM} \mathrm{KCl}$, $1.2 \mathrm{mM} \mathrm{KH}_{2} \mathrm{PO}_{4}, 1.0 \mathrm{mM} \mathrm{CaCl}_{2}, 1.2 \mathrm{mM} \mathrm{MgSO}_{4}, 5.0 \mathrm{mM}$ $\mathrm{NaHCO}_{3}$ and $10.0 \mathrm{mM}$ HEPES. In the insulin-treated group, the cells were then exposed to $3.60 \mathrm{IU} / \mathrm{ml}$ insulin, and $100 \mu \mathrm{l}$ serum-free KRb buffer (supplemented with $160 \mu \mathrm{M} 2-\mathrm{NBDG}$ ) was added to the medium and incubated for $30 \mathrm{~min}$ at $37^{\circ} \mathrm{C}$. The cells were washed twice with $\mathrm{KRb}$ buffer and the radioactivity incorporated into the cells was measured using a fluorescence microplate reader (excitation/emission, 488/520; Model 680, Bio-Rad Laboratories, Inc., Hercules, CA, USA). Subsequently, the medium was replaced with L-DMEM supplemented with $200 \mu \mathrm{l} \mathrm{MTT}$, and continued to culture. After $4 \mathrm{~h}$ incubation at $37^{\circ} \mathrm{C}$, the $\mathrm{OD}$ at $490 \mathrm{~nm}$ was measured using a microplate reader. The error was corrected using an MTT assay.

Measurement of glycogen content. The glycogen levels in the HepG2 cells were determined using a glycogen assay kit in the presence or absence of $3.6 \mathrm{IU} / \mathrm{ml}$ insulin. Briefly, following 3DG treatment of the cells for $24 \mathrm{~h}$, the medium containing L-DMEM was removed and the cells were washed twice with ice-cold phosphate-buffered saline (PBS; Beyotime Institute of Biotechnology) and incubated with serum-free L-DMEM and insulin for $24 \mathrm{~h}$. Subsequently, glycogen in the cells was extracted using $66 \%(\mathrm{v} / \mathrm{v})$ ethanol and centrifuged for $10 \mathrm{~min}$ at $8,000 \times \mathrm{g}$ at $4^{\circ} \mathrm{C}$ to remove the supernatant. The precipitates of each sample were mixed with $0.5 \mathrm{ml}$ water, and the medium was subsequently added into $1 \mathrm{ml} 0.2 \%(\mathrm{w} / \mathrm{v})$ anthrone reagents 
(Rsbio, Shanghai, China). The tubes were boiled for $30 \mathrm{~min}$. Absorbance at $620 \mathrm{~nm}$ was measured using an enzyme-linked immunometric meter. A standard glycogen curve $(50,25,12.5$, $6.25,3.12$ and $1.60 \mathrm{mg} / \mathrm{ml}$ ) was calculated using the above method.

Western blot analysis. The HepG2 cells were rendered insulin resistant by treatment with 3DG, as described above. The medium containing L-DMEM and 3DG was removed from the cells, and the cells were then washed twice with ice-cold PBS and solubilised in IP lysin buffer containing $20 \mathrm{mM}$ Tris (pH 7.5), $150 \mathrm{mM} \mathrm{NaCl}, 1 \%$ Triton X-100, 2 mM SDS, $25 \mathrm{mM} \beta$-glycerophoaphate, $1 \mathrm{mM}$ EDTA, $1 \mathrm{mM} \mathrm{Na}_{3} \mathrm{VO}_{4}$ and $0.5 \mu \mathrm{g} / \mathrm{ml}$ leupeptin (Beyotime Institute of Biotechnology). Following centrifugation at $12,000 \mathrm{x} \mathrm{g}$ at $4{ }^{\circ} \mathrm{C}$ for $20 \mathrm{~min}$, the supernatants were collected and used for Western blot analysis. The total protein concentrations were determined using a bicinchoninic acid protein (BCA) assay kit (cat. no. P0012; Beyotime Institute of Biotechnology) comprised of BCA kit A (cat. no P0012-1), BCA kit B (cat. no. P0012-2) and standard proteins (cat. no. P0012-3). The proteins (80-120 $\mu \mathrm{g}$ ) were loaded onto a 12\% SDS-polyacrylamide gel (Thermo Fisher Scientific, Inc.), then subjected to electrophoresis and transferred onto polyvinylidene fluoride membranes (Merck Millipore, Darmstadt, Germany). The membranes were blocked for $1 \mathrm{~h}$ in Tris-buffered saline with $1 \%$ Tween (TBST; Beijing Solarbio Science \& Technology Co., Ltd., Beijing, China) containing 5\% dry milk. The membranes were washed with PBS containing $0.05 \%$ Tween-20 three times, and incubated at $4^{\circ} \mathrm{C}$ overnight with the following antibodies (dilution, 1:1,000): Rabbit polyclonal anti-glucose transporter 2 (GLUT-2; cat. no. ab54460; Abcam, Cambridge, UK); and rabbit monoclonal anti-glycogen synthase kinase-3 (GSK-3)a/ $\beta$ (cat. no. 5676), rabbit polyclonal anti-p-insulin receptor substrate 1 (IRS-1; cat. no. 3070), rabbit polyclonal anti-phosphoinositide 3-kinase (PI3K)-p85 (cat. no. 4292), rabbit polyclonal anti-PI3K-p110 (cat. no. 4255) and rabbit polyclonal anti-AKT (cat. no. 9272), all purchased from Cell Signaling Technology, Inc., Danvers MA, USA. Following washing 4 times for 5 min each in TBST, the membranes were incubated with goat anti-rabbit secondary antibody [1:1,000; cat. no. GAR0072; Multi Sciences (Lianke) Biotech Co., Ltd., Hangzhou, China] for $2 \mathrm{~h}$ and visualized using an ECL detection kit (Beijing Solarbio Science \& Technology Co., Ltd.). Quantification of protein bands was performed using Image-J software (version 1.42).

Statistical analysis. The results of the experiments are expressed as the mean \pm standard deviation. SPSS software (version 14.0; SPSS, Inc., Chicago, IL, USA) was used for statistical analysis The statistical significance of differences were analyzed using Student's $t$-test. $\mathrm{P} \leq 0.05$ was considered to indicate a statistically significant difference. In the following, $\mathrm{n}$ describes the number of repetitions of independent experiments.

\section{Results}

$3 D G$ does not alter HepG2 cell viability at concentrations between 10 and $300 \mathrm{ng} / \mathrm{ml}$. The HepG2 cells were exposed to

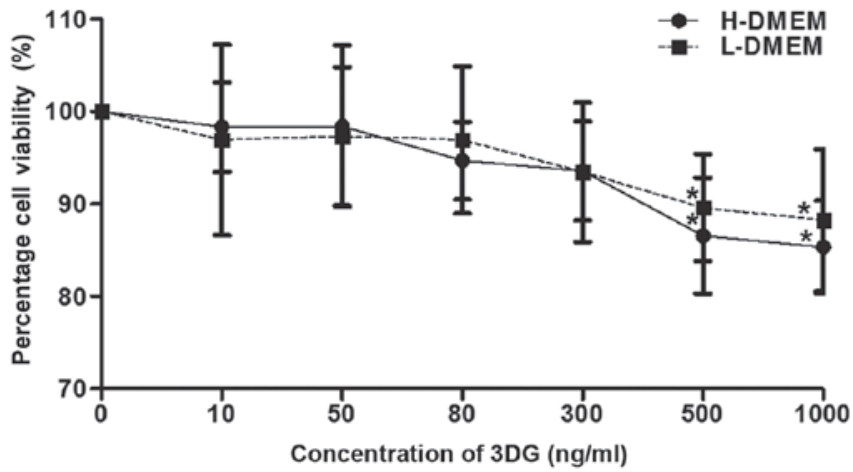

Figure 1. Effects of 3DG treatment on HepG2 cell viability. HepG2 cells incubated with different concentrations of 3DG (10-1,000 ng/ml) in H-DMEM or L-DMEM $(n=5)$. "P<0.05 vs. untreated cells. All data are presented as the mean \pm standard deviation. 3DG, 3-deoxyglucosone; DMEM, Dulbecco's modified Eagle's medium; NC, normal control (untreated cells).

different concentrations of 3DG supplemented with H-DMEM or L-DMEM for $24 \mathrm{~h}$ to examine the effects of 3DG on cell viability. Different concentrations of 3DG were assessed, ranging between 10 and $1,000 \mathrm{ng} / \mathrm{ml}$, and cell viability was measured using an MTT assay. As shown in Fig. 1, compared with the untreated control, 3DG did not alter HepG2 cell viability at concentrations between 10 and $300 \mathrm{ng} / \mathrm{ml}$, whereas 3DG exhibited a degree of inhibitory activity against the growth of the HepG 2 cells at concentrations of 500 or $1,000 \mathrm{ng} / \mathrm{ml}$.

Non-cytotoxic concentrations of $3 D G$ induce decreased 2-NBDG uptake and glycogen content in insulin-stimulated HepG2 cells. To determine whether 3DG leads to hepatic insulin resistance, the uptake of 2-NBDG and glycogen content in the HepG2 cells were measured following treatment with non-cytotoxic concentrations $(10-300 \mathrm{ng} / \mathrm{ml})$ of 3DG for $24 \mathrm{~h}$. Compared with the untreated control cells, 2-NBDG uptake was significantly increased following insulin stimulation $(112.61 \pm 8.42$, vs. $198.85 \pm 15.65 ; \mathrm{P}<0.001)$. The uptake of 2-NBDG remained unchanged in the 3DG-only treated cells, however, the cells co-incubated with $80 \mathrm{ng} / \mathrm{ml}$ $(162.93 \pm 20.49 ; \mathrm{P}<0.05)$ or $300 \mathrm{ng} / \mathrm{ml}(151.44 \pm 11.79 ; \mathrm{P}<0.01)$ 3DG and insulin showed significant dose-dependent decreases in 2-NBDG uptake, compared with the cells exposed to insulin only (198.85 \pm 15.65 ; Fig. 2A). As shown in Fig. 2B, exposure to insulin significantly increased glycogen content, compared with the control $(29.743 \pm 3.712$, vs. $10.151 \pm 1.102 \mu \mathrm{mol} / \mathrm{mg}$, respectively). The cells treated with different concentrations of 3DG showed significant dose-dependent decreases in glycogen content, at concentrations of $80 \mathrm{ng} / \mathrm{ml}(22.060 \pm 1.821 ; \mathrm{P}<0.05)$ and $300 \mathrm{ng} / \mathrm{ml}(16.568 \pm 1.200 \mu \mathrm{mol} / \mathrm{mg} ; \mathrm{P}<0.01)$, compared with the cells exposed to insulin alone $(29.743 \pm 3.712 \mu \mathrm{mol} / \mathrm{mg})$ However, the glycogen content remained unchanged in the 3DG-only treated cells, compared with the normal group. The effect of 3DG treatment became significant from a concentration of $80 \mathrm{ng} / \mathrm{ml}$. Lower concentrations of 3DG did not significantly induce decreased glucose uptake or glycogen content.

Treatment with non-cytotoxic concentrations of $3 D G$ decreases the insulin-induced expression of GLUT2 and $p$-GSK-3a/ $\beta$ in HepG2 cells. To further elucidate the action 


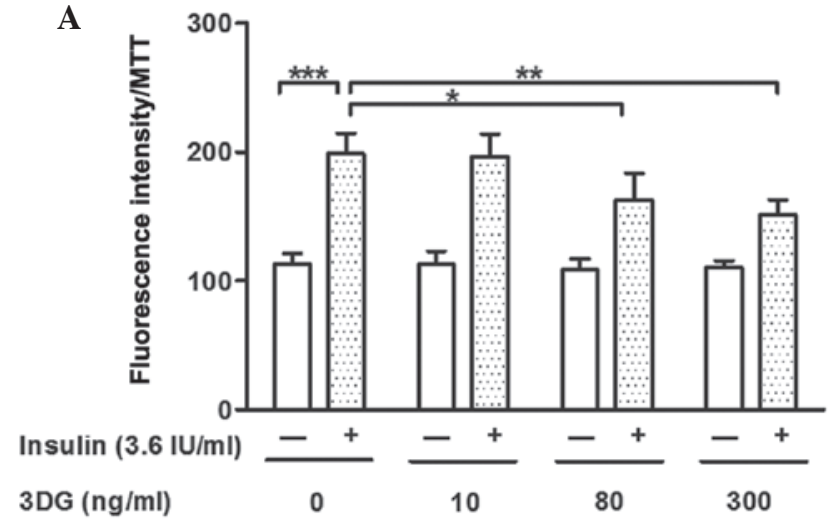

B

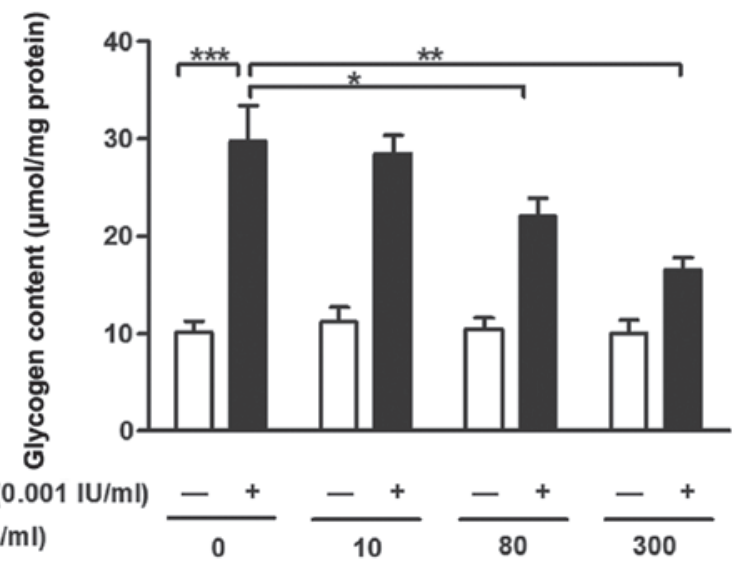

Insulin $(0.001$

Figure 2. Effects of treatment with non-cytotoxic concentrations of 3DG, with and without insulin stimulation, on 2-NBDG uptake and glycogen content in HepG2 cells. (A) HepG2 cells were stained with 2-NBDG for $30 \mathrm{~min}$ following treatment with exogenous 3DG (10, 80 and $300 \mathrm{ng} / \mathrm{ml}, 24 \mathrm{~h})$. Fluorescence intensity was measured on a fluorescence microplate reader, and an MTT assay was used to correct error $(\mathrm{n}=5) .{ }^{* * * *} \mathrm{P}<0.001$, vs. untreated cells; ${ }^{*} \mathrm{P}<0.05$ and ${ }^{* *} \mathrm{P}<0.01$, vs. untreated cells with insulin. (B) Glycogen content in the HepG2 cells was determined using a glycogen assay kit following treatment with exogenous 3DG $(10,80$ and $300 \mathrm{ng} / \mathrm{ml})$ for $24 \mathrm{~h}$ $(n=5) .{ }^{* * *} \mathrm{P}<0.001$, vs. untreated cells; ${ }^{*} \mathrm{P}<0.05$ and ${ }^{* *} \mathrm{P}<0.01$, vs. untreated cells with insulin. Data are presented as the mean \pm standard deviation. 3DG, 3-Deoxyglucosone; 2-NBDG 2-[N-(7-nitrobenz-2-oxa-1,3-diazol-4-yl) amino]-2-deoxyglucose; MTT, 3-(4,5-dimethylthiazol-2-yl)-2,5-diphenyltetra-zolium bromide.

of 3DG, the present study evaluated the expression profile of proteins, which are important for glucose uptake and glycogen content in HepG2 cells. In the present study, treatment of the HepG 2 cells with insulin alone induced a significant increase in the expression levels of GLUT2 and p-GSK-3a/ $\beta$, compared with the control. Although the expression levels of GLUT2 and p-GSK-3a/ $\beta$ were not altered by non-cytotoxic concentrations of 3DG in the 3DG-only treated celss, significant decreases in the protein expression levels of GLUT2 and p-GSK-3a/ $\beta$ were observed following exposure of the cells to $3 \mathrm{DG}$ at concentrations of 80 and $300 \mathrm{ng} / \mathrm{ml}$ for $24 \mathrm{~h}$ with insulin stimulation (Fig. 3).

Effects of non-cytotoxic concentrations of 3DG on insulin signaling in HepG2 cells: Expression and phosphorylation of IR- $\beta$, IRS-1, PI3K-p85, PI3K-p110 and AKT. Glucose uptake and glycogen synthesis in the liver are regulated via the activation of IRS-1, PI3K and AKT (30). Exogenous 3DG treatment

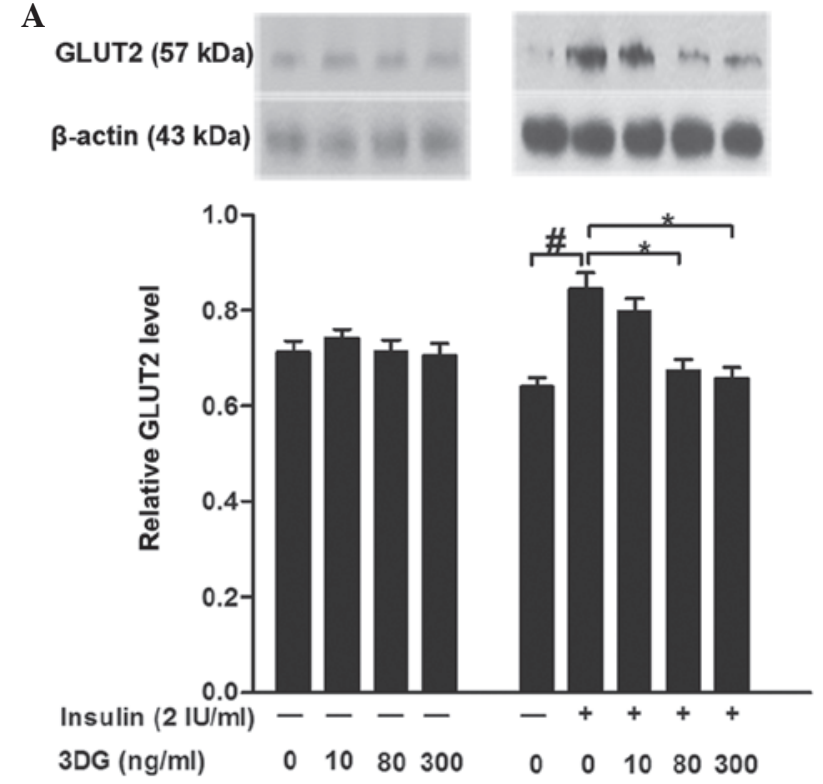

B

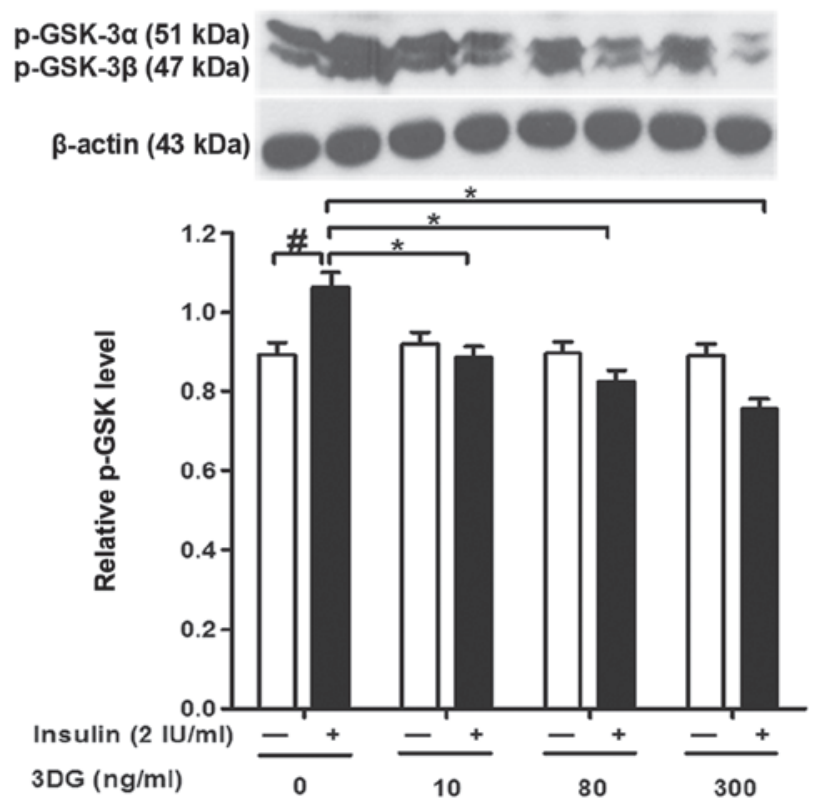

Figure 3. Effects of non-cytotoxic concentrations 3DG on protein expression levels of GLUT2 and p-GSK-3a/ $\beta$ in HepG2 cells with and without insulin ( $2 \mathrm{IU} / \mathrm{ml} ; 30 \mathrm{~min}$ ). (A) Representative Western blot analysis of the expression levels of GLUT2 in HepG2 cells following treatment with or without exogenous 3DG $(10,80$ and $300 \mathrm{ng} / \mathrm{ml})$ for $24 \mathrm{~h}(\mathrm{n}=3) .{ }^{*} \mathrm{P}<0.05$, vs. untreated cells; ${ }^{*} \mathrm{P}<0.05$ vs. untreated cells with insulin. (B) Representative Western blot analysis of the expression levels of p-GSK-3a/ $\beta$ in HepG2 cells following treatment with or without exogenous 3DG $(10,80$ and $300 \mathrm{ng} / \mathrm{ml})$ for $24 \mathrm{~h}(\mathrm{n}=3) .{ }^{\#} \mathrm{P}<0.05$, vs. untreated cells; ${ }^{*} \mathrm{P}<0.05$, vs. untreated cells with insulin. Data are presented as the mean \pm standard deviation. 3DG, 3-Deoxyglucosone; GLUT2, glucose transporter 2; p-GSK-3, phosphorylated glycogen synthase kinase-3.

had no significant effect on the expression levels of IR- $\beta$ and IRS-1, however, treatment of the cells with $300 \mathrm{ng} / \mathrm{ml}$ 3DG reduced the insulin-stimulated tyrosine phosphorylation of IRS-1 (Fig. 4A). To investigate the consequences of the reduced tyrosine phosphorylation of IRS-1, the expression levels of the downstream target proteins, PI3K-p85, PI3K-p110, AKT and 
A
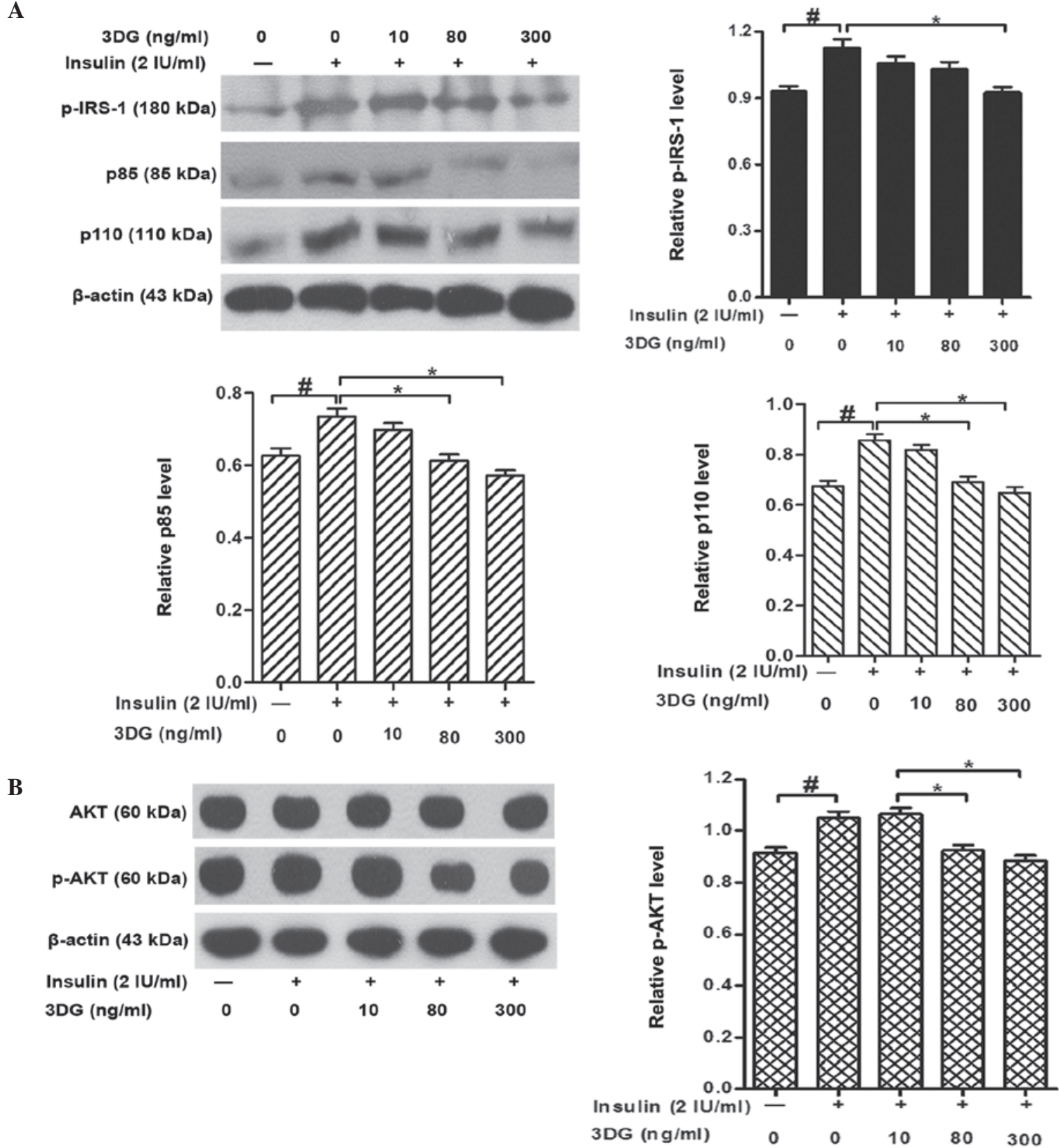

Figure 4. Effect of non-cytotoxic concentrations 3DG on insulin signalling in HepG2 cells. HepG2 cells were incubated for $24 \mathrm{~h}$ with or without 3DG at non-cytotoxic concentrations and then stimulated for $30 \mathrm{~min}$ with $2 \mathrm{IU} / \mathrm{ml}$ insulin $(\mathrm{n}=3)$. Western blot analysis was used to determine the expression levels of (A) p-IRS-1, PI3K-p85 and PI3K-p110, and (B) p-AKT in the HepG2 cells. ${ }^{\text {} P}<0.05$, vs. untreated cells; ${ }^{*} \mathrm{P}<0.05$, vs. untreated cells with insulin. Data are presented as the mean \pm standard deviation. 3DG, 3-Deoxyglucosone; IRS-1, insulin receptor substrate-1; PI3K, phosphoinositide 3-kinase; p-, phosphorylated.

p-AKT, were determined. As shown in Fig. 4A, 3DG treatment induced significant decreases in the protein expression levels of the PI3K p85 and p110 subunits. Furthermore, 3DG led to a dose-dependent decrease in the phosphorylation of AKT, which was not accompanied by changes in the level of AKT (Fig. 4B).

\section{Discussion}

Insulin is important in the stimulation of glucose uptake, the impairment of which is a major factor responsible for insulin resistance. In additional, insulin acts by decreasing glucose production and enhancing its storage as glycogen in hepatocytes, the disorder of which is also considered to be an underlying mechanism of insulin resistance $(6,7,31)$. In the present study, it was observed that exposure of the HepG2 cells to 3DG for $24 \mathrm{~h}$ at concentrations of 80 and $300 \mathrm{ng} / \mathrm{ml}$ decreased glucose uptake and glycogen content with insulin stimulation, but had no effect on glucose uptake or glycogen content in the absence of insulin (Fig. 2). In addition, decreased glucose consumption was observed in the 3DG-treated HepG2 cells following stimulation with insulin (data not shown). In agreement with a study by Kiho et al (17), these results suggested the association between 3DG and the development of insulin resistance.

In hepatocytes, the primary mechanism of insulin-stimulated glucose uptake and release in the fed and fasted states, respectively, is through GLUT2, which has a low apparent affinity for glucose $(K m \sim 17 \mathrm{mmol} / \mathrm{l})$ and is expressed at high 
levels in the liver $(32,33)$. The high $K m$ value for glucose indicates that the rate of glucose transport by GLUT2 varies with the concentrations of glucose under physiological conditions. In the present study, the expression level of GLUT2 was reduced significantly following exposure of the HepG2 cells to 3DG at 80 and $300 \mathrm{ng} / \mathrm{ml}$ for $24 \mathrm{~h}$ with insulin stimulation. However, in the absence of insulin, no significant decrease in the expression level of GLUT2 was observed (Fig. 3A). However, the precise role of GLUT2 in glucose transport in the liver remains to be fully elucidated. Another glucose transporter isoform, GLUT1, which shows low levels of expression in hepatocytes, has been identified to collaborate with GLUT2 to mediate glucose uptake (34). In the present study, it was shown that the protein expression of GLUT1 was reduced following stimulation with insulin and treatment of the HepG2 cells with 3DG (data not shown). Furthermore, the effect of 3DG on GLUT2 in fed and fasted states in animal models is under investigation. GSK-3 is a serine/threonine kinase, which is associated with several diseases, including cancer, diabetes, inflammation, and Alzheimer's disease $(35,36)$. It has been reported that GSK-3 inactivation is involved in the positive regulation of hepatocellular carcinoma cell proliferation $(37,38)$. In addition, insulin phosphorylates and inactivates GSK-3, leading to the activation of the glycogen synthase (GS), which is responsible for the storage of glucose in the liver (39). Therefore, the activation of GSK-3 promotes the phosphorylation and inactivation of GS, thereby decreasing glycogen synthesis. The findings in the HepG2 cells in the present study were consistent with the above. Although the expression level of p-GSK-3 was not altered by 3DG treatment under basal conditions, a reduction in the phosphorylation of GSK-3 was observed in the 3DG-treated cells stimulated with insulin (Fig. 3B). In the 3DG-only treated cells, the HepG2 cell viability was inhibited at concentrations of 500 and $1,000 \mathrm{ng} / \mathrm{ml}$ (Fig. 1), possibly due to mechanisms including the decreased expression of GLUT1 (40) and phosphorylation of GSK-3. In addition, it has been shown that 3DG can induce the apoptosis of U937 monocytic leukemia cells (41), and the results of the present study indicated that 3DG directly impaired insulin action in the HepG2 cells.

Insulin signaling pathways, for example the IR/IRS/PI3K/AKT signaling pathway, are important in regulating the expression of GLUT2 (42-44) and GSK-3 $(7,45,46)$. When insulin binds to IR, the intrinsic tyrosine kinase activity of IR is activated. The activated receptor then phosphorylates its own receptor and IRS, thereby dissociating IRS from IR to bind the PI3K regulatory subunit, p85, following which the p110 subunit is activated. Activated PI3K produces phosphatidylinosito $(3,4,5)$-triphosphate via the phosphorylation of phosphatidylinosito (4,5)-bisphosphate, and activates AKT through binding. The activated AKT inactivates GSK-3 at $\operatorname{ser}^{9} /^{21}$ and activates GLUT2 to enhance glucose uptake (47). To clarify the effect of 3DG on insulin signaling, the present study directly treated HepG2 cells with 3DG. Reductions in the phosphorylation of IRS-1 and AKT, and in the expression levels of PI3K-p110 and PI3K-p85 were observed (Fig. 4). These results indicated that treatment of the cells with $3 \mathrm{DG}$ may have induced significant decreases in the protein expression levels of GLUT2 and p-GSK-3 by impairing the insulin signaling pathway.

$3 \mathrm{DG}$, a reactive 1,2-dicarbonyl compound, is formed non-enzymaticallly in the course of the Maillard reaction and in the caramelization processes in food $(12,48)$. The contents of 3DG in foods, including balsamic vinegar, honey and bakery products, have been published $(49,50)$. In addition to the Maillard reaction, 3DG is also synthesized via fructoseamine-3-kinase (51) and the polyol pathway (52) in vivo. In the present study, it was observed that the direct addition of exogenous 3DG contributes to insulin resistance in HepG2 cells. These results suggested that 3DG may be involved in inducing impaired glucose regulation and worsening of the diabetic condition as the plasma concentration of 3-DG is elevated. Therefore, 3DG may offer potential as a novel target for the prevention and therapy of diabetes and its complications.

In conclusion, the present study demonstrated for the first time, to the best of our knowledge, that exogenous 3DG impaired insulin signaling, which may have led to decreased insulin-stimulated glucose uptake and glycogen synthesis, and contributed to insulin resistance in the HepG2 cells. These findings, in combination with those of previous studies $(24,25)$ indicated that $3 \mathrm{DG}$ is an independent factor contributing to insulin resistance. Further elucidation of this novel 3DG-mediated mechanism may assist in establishing novel and more effective preventative strategies to improve prevention and treatment in patients with insulin resistance and type 2 diabetes. Reducing the ingestion and production of exogenous or endogenous 3DG, respectively, may be applied for the clinical management of diabetes due to 3DG being a potential risk factor for the progression of diabetes.

\section{Acknowledgements}

This study was supported by research funds from the Suzhou Science and Technology Department (grant nos. SYS201423 and SYS201153) and the Suzhou Youth Science and Education Project (grant no. KJXW2014027).

\section{References}

1. Petersen KF and Shulman GI: New insights into the pathogenesis of insulin resistance in humans using magnetic resonance spectroscopy. Obesity (Silver Spring) 14 (Suppl 1): S34-S40, 2006.

2. Gallagher EJ, LeRoith D and Karnieli E: The metabolic syndrome-from insulin resistance to obesity and diabetes. Endocrinol Metab Clin North Am 37: 559-579, 2008.

3. Goldstein BJ: Insulin resistance as the core defect in type 2 diabetes mellitus. Am J Cardiol 90: 3G-10G, 2002.

4. Taniguchi CM, Ueki K and Kahn R: Complementary roles of IRS-1 and IRS-2 in the hepatic regulation of metabolism. J Clin Invest 115: 718-727, 2005.

5. Hunter SJ and Garvey WT: Insulin action and insulin resistance: Diseases involving defects in insulin receptors, signal transduction and the glucose transport effector system. Am J Med 105: 331-345, 1998.

6. Leclercq IA, Da Silva Morais A, Schroyen B, Van Hul N and Geerts A: Insulin resistance in hepatocytes and sinusoidal liver cells: Mechanisms and consequences. J Hepatol 47: 142-156, 2007.

7. Dou L, Zhao T, Wang L, Huang X, Jiao J, Gao D, Zhang H, Shen T, Man Y, Wang S and Li J: miR-200s contribute to interleukin-6 (IL-6)-induced insulin resistance in hepatocytes. J Biol Chem 288: 22596-22606, 2013.

8. Sechi LA and Bartoli E: Mechanisms of insulin resistance leading to hypertension: What we can learn from experimental models. J Investig Med 45: 238-251, 1997.

9. Shin D B, Hayase F and Kato H: Polymerization of proteins caused by reaction with sugars and the formation of 3-deoxyglucosone under physiological conditions. Agric Biol Chem 52: 1451-1458, 1988. 
10. Kusunoki H, Miyata S, Ohara T, Liu BF, Uriuhara A, Kojima H, Suzuki K, Miyazaki H, Yamashita Y, Inaba K and Kasuga M: Relation between serum 3-deoxyglucosone and development of diabetic microangiopathy. Diabetes Care 26: 1889-1894, 2003.

11. Supplementto American Academy of Dermatology 66th Annual Meeting: Inhibitors of 3-deoxyglucosone (3DG) treat aging and inflamed skin by preventing the form action of AGEs, oxidative stress and free radicals. San Antonio, Texas: J Am Acad Dermatol 231, 2008.

12. Niwa T: 3-Deoxyglucosone: Metabolism, analysis, biological activity and clinical implication. J Chromatogr B Biomed Sci Appl 731: 23-36, 1999.

13. Lal S, Kappler F, Walker M, Orchard TJ, Beisswenger PJ, Szwergold BS and Brown TR: Quantitation of 3-deoxyglucosone levels in human plasma. Arch Biochem and Biophys 342: 254-260, 1997.

14. Hamada Y, Nakamura J, Fujisawa H, Yago H, Nakashima E, Koh N and Hotta N: Effects of glycemic control on plasma 3 -deoxyglucosone levels in NIDDM patients. Diabetes Care 20: $1466-1469,1997$

15. Beisswenger PJ, Howell SK, O'Dell RM, Wood ME, Touchette AD and Szwergold BS: alpha-Dicarbonyls increase in the postprandial period and reflect the degree of hyperglycemia. Diabetes Care 24:726-732, 2001

16. Sakiyama H, Takahashi M, Yamamoto T, Teshima T, Lee SH, Miyamoto Y, Misonou Y and Taniguchi N: The internalization and metabolism of 3-deoxyglucosone in human umbilical vein endothelial cells. J Biochem 139: 245-253, 2006.

17. Kiho T, Asahi T, Usui S, Matsunaga T and Ukai S: Effect of 3 -deoxyglucosone on the activities of enzymes responsible for glucose metabolism in mouse liver. Biol Pharm Bull 19 1106-1108, 1996

18. Sassi-Gaha S, Loughlin DT, Kappler F, Schwartz ML, Su B, Tobia AM and Artlett CM: Two dicarbonyl compounds, 3-deoxyglucosone and methylglyoxal, differentially modulate dermal fibroblasts. Matrix Biol 29: 127-134, 2010.

19. Dhar A, Desai KM and Wu L: Alagebrium attenuates acute methylglyoxal-induced glucose intolerance in Sprague-Dawley rats. Br J Pharmacol 159: 166-175, 2010.

20. Jia X and Wu L: Accumulation of endogenous methylglyoxal impaired insulin signaling in adipose tissue of fructose-fed rats. Mol Cell Biochem 306: 133-139, 2007.

21. Dhar A, Dhar I, Jiang B, Desai KM and Wu L: Chronic methylglyoxal infusion by minipump causes pancreatic beta-cell dysfunction and induces type 2 diabetes in Sprague-Dawley rats. Diabetes 60: 899-908, 2011.

22. Riboulet-Chavey A, Pierron A, Durand I, Murdaca J, Giudicelli J and Van Obberghen E: Methylglyoxal impairs the insulin signaling pathways independently of the formation of intracellular reactive oxygen species. Diabetes 55: 1289-1299, 2006.

23. Fiory F, Lombardi A, Miele C, Giudicelli J, Beguinot F and Van Obberghen E: Methylglyoxal impairs insulin signalling and insulin action on glucose-induced insulin secretion in the pancreatic beta cell line INS-1E. Diabetologia 54: 2941-2952, 2011.

24. Wang Q, Jiang Gr and Zhang Lr: Effects of 3-deoxyglucosone on blood glucose of normal mice. Chin J Diabetes 18: 220-222, 2010.

25. Jiang $\mathrm{G}$, Zhang $\mathrm{L}$, Ji Q, Wang $\mathrm{F}, \mathrm{Xu} \mathrm{H}$, Huang $\mathrm{F}$ and Wang $\mathrm{C}$ : Accumulation of plasma 3-deoxyglucosone impaired glucose regulation in Chinese seniors: Implication for senile diabetes? Diabetes Metab Syndr 6: 140-145, 2012.

26. Kato H, van Chuyen N, Shinoda T, Sekiya F and Hayase F: Metabolism of 3-deoxyglucosone, an intermediate compound in the Maillard reaction, administered orally or intravenously to rats. Biochim Biophys Acta 1035: 71-76, 1990

27. Jiang GL, Zhang LV, Wang F, Xu H and Fei D: Synthesis and structure analysis of the 3-deoxyglucosone (3-DG). J Soochow Univ 27: 60-68, 2011

28. Zhang L, Jiang G, Yao F, He Y, Liang G, Zhang Y, Hu B, Wu Y, $\mathrm{Li} \mathrm{Y}$ and Liu H: Growth inhibition and apoptosis induced by osthole, a natural coumarin, in hepatocellular carcinoma. PLoS One 7: e37865, 2012.

29. Engelbrecht B, Mattern Y, Scheibler S, Tschoepe D, Gawlowski T and Stratmann B: Methylglyoxal impairs GLUT4 trafficking and leads to increased glucose uptake in L6 myoblasts. Horm Metab Res 46: 77-84, 2014.
30. Cordero-Herrera I, Martín MÁ, Goya L and Ramos S: Cocoa flavonoids attenuate high glucose-induced insulin signalling blockade and modulate glucose uptake and production in human HepG2 cells. Food Chem Toxicol 64: 10-19, 2014.

31. Schinner S, Scherbaum WA, Bornstein SR and Barthel A: Molecular mechanisms of insulin resistance. Diabetic Med 22: 674-682, 2005

32. Mueckler M and Thorens B: The SLC2 (GLUT) family of membrane transporters. Mol Aspects Med 34: 121-138, 2013.

33. Hosokawa M and Thorens B: Glucose release from GLUT2-null hepatocytes: Characterization of a major and a minor pathway. Am J Physiol Endocrinol Metab 282: E794-E801, 2002.

34. Levitsky LL, Zheng Q, Mink K and Rhoads DB: GLUT-1 and GLUT-2 mRNA, protein, and glucose transporter activity in cultured fetal and adult hepatocytes. Am J Physiol 267: E88-E94, 1994.

35. Martinez A, Castro A, Dorronsoro I and Alonso M: Glycogen synthase kinase 3 (GSK-3) inhibitors as new promising drugs for diabetes, neurodegeneration, cancer and inflammation. Med Res Rev 22: 373-384, 2002.

36. Medina $\mathrm{M}$ and Castro A: Glycogen synthase kinase-3 (GSK-3) inhibitors reach the clinic. Curr Opin Drug Discov Devel 11: 533-543, 2008

37. Ban KC, Singh H, Krishnan R and Seow HF: GSK-3beta phosphorylation and alteration of beta-catenin in hepatocellular carcinoma. Cancer Lett 199: 201-208, 2003.

38. Ibrahim SH, Akazawa Y, Cazanave SC, Bronk SF, Elmi NA, Werneburg NW, Billadeau DD and Gores GJ: Glycogen synthase kinase-3 (GSK-3) inhibition attenuates hepatocyte lipoapoptosis. J Hepatol 54: 765-772, 2011.

39. Nachar A, Vallerand D, Musallam L, Lavoie L, Badawi A, Arnason J and Haddad PS: The action of antidiabetic plants of the canadian james bay cree traditional pharmacopeia on key enzymes of hepatic glucose homeostasis. Evid Based Complement Alternat Med 2013: 189819, 2013.

40. Xu YY, Wu TT, Zhou SH, Bao YY, Wang QW, Fan J and Huang YP: Apigenin suppresses GLUT-1 and p-AKT expression to enhance the chemosensitivity to cisplatin of laryngeal carcinoma Hep-2 cells: An in vitro study. Int J Clin Exp Pathol 7: 3938-3947, 2014.

41. Okado A, Kawasaki Y, Hasuike Y, Takahashi M, Teshima T, Fujii J and Taniguchi N: Induction of apoptotic cell death by methylglyoxal and 3-deoxyglucosone in macrophage-derived cell lines. Biochem Biophys Res Commun 225: 219-224, 1996.

42. Song Z, Wang H, Zhu L, Han M, Gao Y, Du Y and Wen Y: Curcumin improves high glucose-induced INS-1 cell insulin resistance via activation of insulin signaling. Food Function 6: 461-469, 2015.

43. Ruan CT, Lam SH, Chi TC, Lee SS and Su MJ: Borapetoside C from Tinospora crispa improves insulin sensitivity in diabetic mice. Phytomedicine 19: 719-724, 2012.

44. Manna P and Jain SK: Decreased hepatic phosphatidylinositol-3,4,5-triphosphate (PIP3) levels and impaired glucose homeostasis in type 1 and type 2 diabetic rats. Cell Physiol Biochem 30: 1363-1370, 2012.

45. Wang ZB, Zeng HC, Wei HS, Yi GH, Yu J, Wang YT, Zhang YL and Yin WD: NO-1886 ameliorates glycogen metabolism in insulin-resistant HepG2 cells by GSK-3 $\beta$ signalling. J Pharm Pharmacol 64: 293-301, 2012

46. Lavoie L, Band CJ, Kong M, Bergeron JJ and Posner BI: Regulation of glycogen synthase in rat hepatocytes. Evidence for multiple signaling pathways. J Biol Chem 274: 28279-28285, 1999.

47. Saltiel AR and Kahn CR: Insulin signalling and the regulation of glucose and lipid metabolism. Nature 414: 799-806, 2001.

48. Kroh LW: Caramelisation in food and beverages. Food Chem 51: 373-379, 1994.

49. Hellwig M, Degen J and Henle T: 3-deoxygalactosone, a 'new' 1,2-dicarbonyl compound in milk products. J Agric Food Chem 58: 10752-10760, 2010.

50. Degen J, Hellwig M and Henle T: 1,2-dicarbonyl compounds in commonly consumed foods. J Agric Food Chem 60: 7071-7079, 2012.

51. Brown TR, Su B, Brown KA, Schwartz MA, Tobia AM and Kappler F: Modulation of in vivo 3-deoxyglucosone levels. Biochem Soc Trans 31: 1433-1437, 2003.

52. Lal S, Szwergold BS, Taylor AH, Randall WC, Kappler F, Wells-Knecht K, Baynes JW and Brown TR: Metabolism of fructose-3-phosphate in the diabetic rat lens. Arch Biochem Biophys 318: 191-199, 1995 